p-ISSN. 2086-9029

e-ISSN. 2654-5675

Vol. 22 No. 1, Hlm. 1-158, Juni 2020

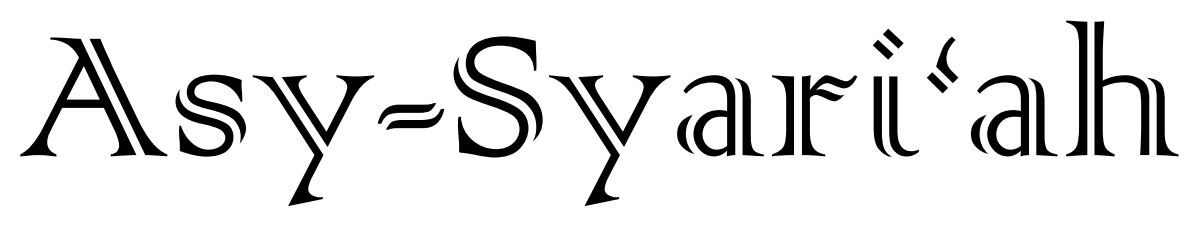

- Hukum Waris Islam Sebagai Instrumen Kepemilikan Harta

$(1-20)$ Hafidz Taqiyyudin

- Komparasi Metodologi Hukum Aliran Maqasidi dan Aliran Syakli

$(21-34)$ Hudzaifah Achmad Qotadah

- Reinterpretasi Hak Ijbar dalam Hukum Perkawinan Islam di Keluarga $(35-50)$ Pesantren

Kudrat Abdillah

- Dimensi Kondisionalitas dan Fleksibilitas Al-Quran bagi Implementasi $(51-66)$ Fatwa DSN-MUI tentang Produk Bank Syariah

Ahmad Hasan Ridwan, Asep Rahmat

- Validitas Hadis Tidak Ada Kisas bagi Orang Tua yang Membunuh Anaknya

Moh. Ahsanuddin Jauhari, Enceng Arif Faizal, Syahrul Anwar, Atep Mastur, Deden Najmudin

- Penguatan Resolusi Konflik Berbasis Tradisi Sunnah Nabi

Alamsyah

- Sistem Perencanaan, Pelaksanaan dan Pengawasan Industri Halal di Wilayah Provinsi Banten

Akhyakudin, Suja'i, Muhammad Abduh

- Reformulation of Family Legal in Indonesia for Female Maslahah

Wahidullah, Murniati, Yushinta Eka Farida, Jumaiyah

- The Concept and Aplication of Covenant in Financing Gold Pawn By Sharia Bank in West Java

Neni Nuraeni, Dewi Sulastri, Zulbaidah

- Tinjauan Sosiologi Hukum tentang Kepatuhan Masyarakat terhadap ( $147-158)$ Undang-Undang Wakaf

Deden Effendi

FACULTY OF SHARIA AND LAW

STATE ISLAMIC UNIVERSITY SUNAN GUNUNG DJATI BANDUNG-INDONESIA IN COLLABORATION WITH ASOSIASI SARJANA SYARIAH INDONESIA 


\section{Asy-Syari'ah}

Volume 22, Number 1, 2020

\section{EDITOR-IN-CHIEF}

Ine Fauzia

\section{EDITORIAL BOARD}

Sofyan al-Hakim, UIN Sunan Gunung Djati Bandung, Indonesia Deni Kamaludin Yusup, UIN Sunan Gunung Djati Bandung, Indonesia Meria Utama, Fakultas Hukum Univrsitas Sriwijaya, Indonesia Dewi Mayaningsih, UIN Sunan Gunung Djati Bandung, Indonesia Andrey Sujatmiko, Fakultas Hukum Universitas Trisakti, Jakarta, Indonesia Hetty Hassanah, Universitas Komputer Indonesia, Indonesia

\section{PEER-REVIEWERS}

Muhammad Irfan Helmy, IAIN Salatiga, Semarang, Indonesia Ahmad Ali Nurdin, UIN Sunan Gunung Djati Bandung Tajul Arifin, UIN Sunan Gunun Djati Bandung, Indonesia Mohamad Anton Athoillah, UIN Sunan Gunung Djati Bandung, Indonesia Mrs. Renny Supriyatni, Universitas Padjadjaran, Indonesia Ahmad Tholabi Karlie, UIN Syarif Hidayatullah Jakarta, Indonesia Ija Suntana, UIN Sunan Gunung Djati Bandung, Indonesia Zezen Zaenal Mutaqin, University of California, Los Angeles, United States Ahmad Fathonih, UIN Sunan Gunung Djati Bandung, Indonesia Rahman Syamsuddin, Universitas Islam Negeri Alauddin Makassar, Indonesia

\section{PROOFREADER/DESIGN COVER}

Nanang Sungkawa

\section{LAYOUT EDITOR}

Opik Rozikin

Asy-Syari' ah has been accredited based on the determination of Director General of Research and Development Strengthening, Ministry of Research, Technology and Higher Education of Republic of Indonesia, No. 14/E/KPT/2019 (valid until 2023). 


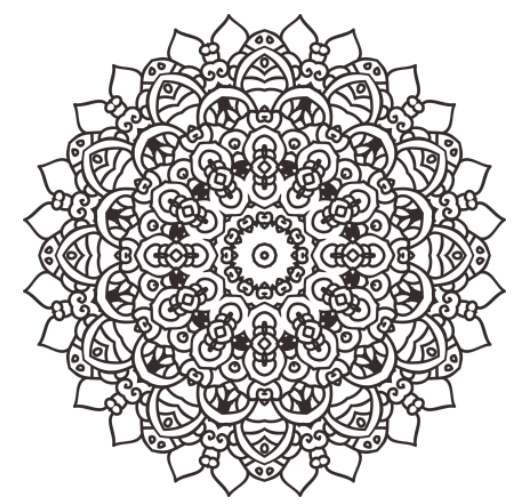

\title{
REFORMULATION OF FAMILY LEGAL IN INDONESIA FOR FEMALE MASLAHAH
}

\author{
${ }^{1}$ Wahidullah ${ }^{2}$ Murniati ${ }^{3}$ Yushinta Eka Farida ${ }^{4}$ Jumaiyah \\ ${ }^{1}$ Fakultas Syariah dan Hukum Universitas Islam Nahdlatul Ulama Jepara \\ ${ }^{2}$ Fakultas dakwah dan Komunikasi' Universitas Islam Nahdlatul Ulama Jepara \\ ${ }^{3}$ Fakultas Tarbiyah dan ilmu Keguruan Universitas Islam Nahdlatul Ulama Jepara \\ ${ }^{4}$ Fakultas Ekonomi \& Bisnis Universitas Islam Nahdlatul Ulama Jepara \\ E-mail:wahidullah@unisnu.ac.id; murniati@unisnu.ac.id; faridayushinta@gmail.com; \\ mayawahidah@unisnu.ac.id
}

\begin{abstract}
In Law Number 1 in 1974 article 3 section 1 and 2, providing an explanation of the marriage principle is monogamous but is open, or in $\mathrm{KHI}$ using the term polygamy is limited to four wives, but with a record of the ability to provide and do justice towards his wives and children. Households that are built based on polygamy are part of a community that is a matter of controversy, but legal normativeity has been ratified and that a social reality occurs. The method is used in this study by collecting data in the form of literature research, as for the steps in this study by reading literature in the form of books, articles, legislation, and fatwas. The data is analyzed by qualitative descriptive method in order to obtain research results based on theories related to research The results showed that there were no women who were willing to be polygamous. In the case of polygamy, women are the object of violence wrapped neatly in household life.
\end{abstract}

Keywords: Women, Polygamy Victims, Injustice in Households, monogamy 


\begin{abstract}
Abstrak: Di dalam Undang-undang Nomor 1 tahun 1974 Pasal 3 ayat 1 dan 2, memberikan penjelasan tentang asas perkawinan adalah monogami akan tetapi bersifat terbuka, atau dalam $\mathrm{KHI}$ menggunakan istilah poligami terbatas sampai dengan empat isteri, akan tetapi dengan catatan kemampuan memberi nafkah dan berbuat adil terhadap isteriisteri dan anak-anaknya. Rumah tangga yang dibangun berdasarkan poligami sebagian masyarakat menjadi hal yang kontroversi, akan tetapi normatifitas hukum telah disahkan dan itu sebuah realitas sosial terjadi. Metode yang digunakan dalam penelitian ini dengan mengumpulkan data berupa pustaka pustaka (literature research), adapun langkahlangkah dalam penelitian ini dengan membaca literatur berupa buku, artikel, peraturan perundang-undangan serta fatwa. Data tersebut di analisis dengan metode deskriftif kualitatif guna memperoleh hasil penelitian dengan berpijak pada teori yang terkait dengan penelitian Hasil penelitian menunjukan bahwa tidak ada perempuan yang rela di poligami. Pada kasus poligami perempuan merupakan obyek kekerasan yang terbungkus rapi dalam kehidupan rumahtangga.
\end{abstract}

Kata kunci: Perempuan, Korban Poligami, Ketidakadilan Dalam Rumahtangga, Monogami 


\section{Introduction}

As the provisions of the Marriage Law Number 1 of 1974 concerning marriages explain that marriages in Indonesia following the principle of monogamy are not absolute or open, it can be seen in Article 3 paragraphs 1 and 2, namely (1) In principle in a marriage a man may only have a wife. A woman can only have a husband. (2) The court may give permission for a husband to have more than one wife if desired by the party concerned.

In the Compilation of Islamic Law $(\mathrm{KHI})$ also provides provisions for limiting the number of wives, ie up to four wives. This means that for Muslims in carrying out marriage it is permissible to polygamy but is limited, Article 55 paragraph 1 reads that:

" Having more than one wife at a time, limited to four wives. "

The husband's desire to carry out limited polygamy must go through permission from the court, with the fulfillment of several conditions including the approval of his wife or wives as Article 5 a UUP, items $b$ and c. Besides that, certainty must be guaranteed for fulfilling the necessities of life (needs) of wives and children, and there is a guarantee of being fair to wives and children. This is then in the arrangement of those intending to polygamy through government regulations in the year of the Republic of Indonesia Government Regulation Number 9 of 1975 Concerning the Implementation of Law Number 1 of 1974 concerning Marriage, the court conducted an examination of its proposed will.

Provisions on guarantees for fair conduct are still in favor of the husband, not the wives and children. That is the range of denial of the promise (statement), and formalistic to fulfill the will of polygamy. This reasoning is based on the first absence of operational derivatives in form of doing justice, secondly, there is no provision for doing justice as stipulated in an agreement in this case in a marriage agreement, thirdly there is no understanding of the community especially wives about the rights obtained in marriage. fourth, marriages are only interpreted as ordinary civil law events, so that when a breach of agreement occurs, one of the parties suffers from a lawsuit.So in Article 41 government regulations seem formalamistic, different if Article 41 is cumulative in nature, meaning that the requirements for polygamy must be fulfilled and through proof as an argument for proposing polygamy. This is then foresight, the accuracy of the judge determines whether or not he is allowed to polygamy as a claimant.

The above foundation regarding the weakness of the provision of polygamy as a translation of the husband's fairness to his wives and children who are in the $\mathrm{KHI}$ is the main condition for polygamy so that if the possibility of not fulfilling is fair then polygamy is a prohibition, it can be seen in Article 55 paragraph 2 and 3 stated that: (2) The main requirement for more than one wife, the husband must be able to be fair to his wives and 
children. (3) If the main conditions mentioned in paragraph (2) cannot be fulfilled, the husband is prohibited from having a wife from a wife.

In the context above Nur Khoirin YD, in his article entitled Questioning the Polygamy Permit for Civil Servants in 2010, opposed the polygamy procedure which is now burdensome with his conclusions to facilitate the polygamy procedure for the husband. As for doing justice and the ability to guarantee a living for the family is left to them, because they know and who will lead a married life.

Although the normativeity of polygamy marriages is permitted, according to Nasaruddin Umar (deputy minister of religion) that polygamous marriages are considered as one of the factors causing the increase in divorce rates in Indonesia. ( www.kemenag.go.id) supported by Sayuti Asyathri, member of the House of Representatives commission II in the 2006 workshop Socialization of the Law on Population, Utilization, and Population Registration Related to the Population Administration Information System, stated that polygamy marriages and the flow of trust were considered difficult to create a database population.

In Pancasila, the word fair is repeated 2 (two) times, namely in the second and fifth precepts, with the content that fairness is an urgency in managing life, even according to Islamic teachings (al-Qur'an) doing justice is a barometer of a person's piety. This is what then does justice in polygamy marriages to become the main base so that what becomes the purpose of marriage can be realized as mandated by Law Number 1 of 1974 in Article 1. And how the data according to records from Religious Courts throughout Indonesia, in 2004 , occurred 813 divorce due to polygamy. set of things above in the context of meaning of law, that the law is not only text editors (law in book) in the form of legal norms alone but also the effectiveness of the implementation of the law (law in action) and even then a separate law, because there are events, legal actions, there are also rights and obligations. This is then the allegations, or initial conclusions that polygamy marriage, will not do justice, unhappy and be the cause of divorce at the same time in the population data, then with the sociological approach to research with the theme of the model of justice based on polygamy marriage implemented.

\section{Methodology}

This research builds requirements for polygamy or open monogamous marriage in marriage in Indonesia, as an effort to reform civil law (family law) which is characterized by justice and dignity. The method used is an approach to study the applicable law and be found with facts in the field. 


\section{Results and Discussion Polygamy}

The term polygamy with Arabic terms: التعدد الزوجات means many wives. The word polygamy (Greek) is composed of the word poly or pollus which has many meanings and gamein or gamos which means marriage. Polygamy has two meanings, namely the first meaning polygam ami ie a husband has many wives and secondly polyandri namely a wife has many husbands. ${ }^{1}$ Or the state of marriage with more than one person. To bridge existing understanding, the word polygamy in Indonesia means polygyny. ${ }^{2}$

George Whitecross Paton, quoted by Jaih Mubarok, explained about the civilization of human marriage, that the civilization of human marriage is divided into three eras, namely the stone, bronze and iron civilizations. Likewise Friederick Engel quoted by Arif Budiman also stated, that the evolution of marriage is divided into three phases, first the phases of the marriage of wild people, second, the phases of barbarian marriages, the third phase of civilized marriages. ${ }^{3}$ The three phases of classification or civilization of human marriage mentioned in broad outline above indicate the sexual or biological needs of men who also rely on human power (men) over women.

It later became dianta $r$ a a weld lowered doctrine ( asbab al-nuzul) of the Qur'an which is the answer to human mating behavior, where civilization pre-Islamic Arab society marriage has the shape kinds, namely4: first, istibda 'marriage, second, polyandry, third, maqthu 'marriage (patchwork), fourth. Badal marriage fifth, shighar marriage.

Based on the interpretation of bil al-ma'sur, namely interpreting the verse $Q S$ anNisa '(4): 3 by using the Hadith of the Prophet as a means of interpretation, namely the Hadith narrated by Imam al-Turmudzi means that: "The Prophet (SAS) ordered Ghilan to choose four people out of ten of his wives."

So most (jumhur) scholars allow to study with a limit of four people, ${ }^{5}$ for Muslims. The legal norms contained in the Indonesian marriage law regarding the implementation of the principle of open monogamy as in Article 3 and 4 of the UUP and in the Compilation of Islamic Law (KHI) of limited polygamy paragraph 1 Article 55 of $\mathrm{KHI}$, which then in its technicality to implement the will of polygamy is regulated by Government Regulation RI No. 9 of 1975 concerning Implementation of Law Number 1 of 1974 as stipulated in Articles 40 to 44 , all of them cannot be separated from the original reference, namely Islamic Fiqh. ${ }^{6}$

\footnotetext{
${ }^{1}$ Jaih Mubarok, Pembahurauan Hukum Perkawinan di Indonesia, (Bandung: Simbiosa Rekatama Media, 2015). HIm. 151

${ }^{2}$ Mustafid

${ }^{3}$ Arif Budiman, Pembagian Kerja Secara Seksual: Sebuah Pembahasan Sosiologis Tentang Peran Wanita Di Dalam Masyarakat, 1985, (Jakarta: Gramedia, 1985) hlm.49.

${ }^{4}$ Jaih Mubarok, HIm. 153

${ }^{5}$ Ibid. hlm.153

${ }^{6}$ Busthanul Arifin, Pelembagaan Hukum Islam di Indonesia :Akar Sejarah, Hambatan Dan Prospeknya (t.tp) : Gema Insani Press, 1996) hlm.59
} 
Consequences for husbands who have more than one wife, must do justice to their wives and children, in this case Islamic jurisprudence provides for the provision of time distribution to wives, even that becomes a separate discussion in the marriage chapter. ${ }^{7}$ these provisions must be the same from one another, both in time and quality. So when you want to travel even one wife who is invited to do the fairest distribution by means of a draw between the wives. ${ }^{8}$ Even this method seems very difficult for women to accept, what if the lottery came out by only one person.

\section{Justice}

To answer to do justice, it can be stated about the theory of justice. The theory of justice which is technically as proposed by Arsitoteles, namely justice is divided into 2 (two), namely distributive justice and justice and commutative (justitia commutative). The first justice is proportional, that is, each person gets what is his right and ration, but the ration is not the same as each person according to his proportion, so that in polygamy a husband can give according to his wife's proportion to his child. Likewise a husband must apply the same to the rights of his wife and children without differentiating each person (equlity before the law) which Ariestoteles is known for is commutative justice, ${ }^{9}$ To do justice to his wife or children both distributive and commutative in nature a husband is very difficult to do it because justice feels that it is not the giver but the recipient, especially according to aristoletes giving according to the proportion. The sting justice is very diverse such as psychological justice, sociological justice, legal justice and even justice justice even more justice must be straight without any side of lust. ${ }^{10}$

Justice departs from the word fair can be conceptualized and can be used in four meanings, first , a balanced state, this condition is not one-sided, there is nothing more between one recipient and another recipient, the second equality and a disclaimer of any difference, in this case a husband must not discriminate the existence of his wife, thirdly preserve the individual rights of the recipients, each wife or woman he marries has individual rights in which these rights can be different - between one wife and another and fourth maintain the rights for the continuation of existence, every woman has a different existence between one another where the husband must maintain that existence.$^{11}$

According to Mukti Ali, explaining the Qur'anic ideals for justice is to bring a balance between one wife and another, between one child and another, harmony and

\footnotetext{
${ }^{7}$ Imam Taqiuddin Abi Bakar, Kifayat Al-Ahyar Fi Halli Ghayat Al-Ihtishar, (Surabaya : Hidayah, tt.), hlm.72

${ }^{8}$ Sulaiman Rasjid, Fiqh Islam, (Jakarta: Attahiriyyah, tt). hlm 372

${ }^{9}$ Sudikno Mertokusumo, Mengenal Hukum Suatu Pengantar, cet. V, Yogjakarta: Universitas Atma Jaya Yogjakarta, 2010). hlm.101-102

${ }^{10} \mathrm{M}$ Samson Fajar, Keadilan Dalam Hukum Islam (Tinjauan Multidisipliner Dalam Kasus Poligami ) 34| Al'Adalah Vol. XII, No. 1 Juni 2014

${ }^{11}$ Murtadha Muthahhari, Al-'Adl Ilahy (trj), , (Bandung: Mizan, 1992), hlm. 53-58.
} 
harmony, harmonious in providing good living, spiritual and physical maintenance and bias interpreted in various aspects ${ }^{12}$ with manifest in establishing mental respectively, behavioral attitudes and actions toward each his wife, if drawn on polygamous marriages that balance between the rights of wives and obligations of the husband 's to his wife and children. Mukti Ali continued that the balance means upholding the protection of essential rights namely maqashid al-shari'ah ${ }^{13}$, in the end justice and justice are the most important and substantive in the role of Islamic law, in this case a polygamous marriage, the husband must be able to do the fairest possible justice for his wife and children. And this is very difficult because the one who feels fair is not the one who gives but the one who is given.

\section{Polygamy and family law in Indonesia}

Basically family law in Indonesia on poligami family law reformed in three decades , namely: the period before colonization during the time (Portuguese, English, Dutch, Japanese), at this time the law is still using the law in force at the time that the law Netherlands. the colonial period (the Netherlands) during the Dutch colonial period which was enforced by the Dutch was already strong where the Dutch were able to colonize Indonesia three (3) more abat, and a period of independence. At this time, it was divided into three periods: 1) the Old Order (the leadership of Ir. Sukarno); 2) New Order (under Soeharto's presidency); and (3) the Reformation Period (since the fall of General Soeharto on May 21, 1998 to 2007, the final draft). ${ }^{14}$

Decisions of family law cases in the pre-colonial period make use of the existing Institution, namely the Institution of Tahkim. Peradappun began to change which then formed the Institute of ahlu al-halli wa al-'aqdi (the community agreed to appoint Islamic legal experts in customary law courts), considering that at that time the development of Islam began rapidly. After the formation of the Ahlu al-Halli wa al-'aqdi Institute, it was not long before the Swapraja Institution was called that time as a foyer court, the foyer court was there after the presence of Islamic empires at that time, now known as religious justice.

Indonesia implemented Law No, 22 of 1946, this law was applied especially in the old order period which was perfected with other laws, of course the law would flow according to the needs of the community at that time as well as in Indonesia the new order law underwent changes by involving many people and pressure students to legalize the legal requirements for polygamy and divorce are only recognized if they are decided and registered in court. It was at this stage that the birth of Law number 1 of 1974

\footnotetext{
${ }^{12}$ A.Mukti Ali, Memahami Beberapa Aspek Ajaran Islam, Cet ke II, Bandung: Mizan,1993, hlm. 165.

${ }^{13}$ Ibid. hlm 159 .

${ }^{14}$ Khoiruddin Nasution, Hukum Perdata (Keluarga) Islam Indonesia Perbandingan Hukum Perkawinan di Dunia Muslim, cet. ke-1 (Yogyakarta: ACADEMIA+ TAZZAFA, 2009), hlm. 17-20
} 
concerning Marriage (UUP), which took effect on January 2, 1974, was effective on October 1, 1975. This Act was a milestone for the issuance of implementing regulations such as PP No.9 of 1975, regulations of the Minister of Religion and Minister Internal Affairs, and the RI Supreme Court Directive for judges throughout the archipelago (so that a uniform verdict and argument is made in deciding cases). Also appeared Law No. 10 of 1983 , of course the emergence of some of the regulations there is a chronological event that gave birth to a variety of new rules to obtain justice in the Indonesian state which requires the first lady Tien Soeharto to speak. ${ }^{15}$

Starting from the judges who were unfair in deciding the same case but the outcome of the decision was different then the KHI was born. Although there are many different views about the purpose and function of $\mathrm{KHI}$ Arifin believes that the purpose of $\mathrm{KHI}$ is the unification of the unique law as quoted in the book of Muwaffa 'by Imam Malik. I will further examine the purpose of $\mathrm{KHI}$ to equalize interpretations in Islamic law . Opinion Tahir az-Zahri their KHI facilitate religious judges in deciding cases in courts, especially judges who do not understand the contents of the yellow book and $\mathrm{KHI}$ into Islamic law contextualise the latest as many explanations in the yellow book is not relevant to the current conditions.

\section{Psychological violence and polygamy}

As a result of polygamy leaving many problems, problems experienced by polygamy families continue to be felt by a wife and her children such as lack of affection, lack of shopping, children lacking attention all because of increasing family. How could a husband and husband share their affections for some women? Kesih affection by a woman is the real affection that no bus a expressed in words as mathematical formula one plus one equals two. Many people interpret that when a husband divides the number of meetings with his wives evenly is considered fair, but what is felt by a woman such a thing is not considered fair because love according to a wife cannot be quantitative but is qualitative in a very subjective position at all. Not to mention the family who also needs attention, because more than one wife automatically reduces the attention of a husband's figure. The attention of a father figure to his children is certainly this lack of attention due to the growing family. This feeling is meant by psychological violence which is likely to lead to violence and actual abuse of women, especially in Indonesia .

It is inseparable from the law which is not friendly to women. In this case in marriage law. ${ }^{16}$ According to Musdah Mulia, this is due to the highly gender-biased marriage laws. The patriarchal practice of men abides by the laws made in the law, especially the marriage law (UUP) is very thick. ${ }^{17}$ Problems encountered in the law

\footnotetext{
${ }^{15}$ Ibid, hlm. 50.

${ }^{16}$ Mulia, Siti Musdah, Islam Menggugat Poligami, (Jakarta: PT Gramedia Pustaka Utama, 2004) hlm. 138

${ }^{17}$ Riffat Hasan dan Fatimah Mernissi, Setara di Hadapan Allah, (Yogyakarta: LSPPA, 2000), hlm. 43.
} 
although rejuvenated and renewed for the purpose of religion as a religion of justice (See Surah An-Nahl [16]: 90), including justice for a husband and wife. In addition, it is also as our respect for the Messenger of Allah who truly respects women. ${ }^{18}$

\section{Polygamy during the time of the prophet}

Polygamy that is recommended in Islam is polygamy that is in accordance with the time of the prophet Muhammad, namely protecting widows caused by war at that time and educating children and providing adequate living and doing justice to his wives and all their children. ${ }^{19}$ At present there is no war, there are widows due to divorce and left to die while polygamists are only concerned with mere lust by marrying beautiful young girls. ${ }^{20}$ As a result of polygamy marriages cause endless domestic violence, ranging from jealousy between wives, husband's treatment is different between wives, unequal attention, unequal affection and so on. The real impact of polygamy is violence against women packaged in the household.

The tyranny of men and the passion of their sexuality, exploiting and oppressing women, the destruction of the younger generation and all the problems of the reality of polygamy in the 19th century that have been distorted. As written by the Egyptian theologian Muhammad Abduh (1905), In fact, work is what m ewarnai commentaries and fatwas him critical and innovative. $U$ long the others call him courage, his work was able to peel the reality that there is not only the discourse but the facts presented by because its among the fatwa very remarkable is that he wants polygamy does not exist in the Islamic world ${ }^{21}$ as in Turkey, Tunisia and Syria do not allow citizens to practice polygamy either openly or in private, even a Tunisian president said. ${ }^{22}$

"The family is a milestone of the community and the family can succeed well on the basis of mutual respect and respect between partners. One form of mutual respect and respect is to carry out monogamous marriage".

The reality of polygamy shows the existence of violence especially against women and children, as for the violence experienced by wives and children in the form of psychological violence, physical abuse, the exclusion and even neglect of wives and children, threats to living in harmony and terror and waiver of the wife's rights in the form of sexual needs. ${ }^{23}$

\footnotetext{
${ }^{18}$ Lufaefi Mengkaji Pasal-Pasal Bias Gender Uu Perkawinan: Tawaran Pencegahan Kekerasan Terhadap Perempuan, Ahkam Volume 6 Nomor 2, 2018

${ }^{19}$ Wahid Syarifuddin Ahmad, Status Poligami Dalam Hukum Islam (Telaah atas Berbagai Kesalahan Memahami Nash dan Praktik Poligami), Al-Ahwal, Vol. 6, No. 1, 2013

${ }^{20}$ Siti Hikmah, Fakta Poligami Sebagai Bentuk Kekerasan Terhadap Perempuan, Sawwa - Volume 7, Nomor 2, April 2012

${ }^{21}$ Barbara Freyer Stowasser, Reinterpretasi Gender Wanita dalam al-Qur'an Hadis dan Tafsir, terj. hlm. 313

${ }^{22}$ Ibid., hlm. 17

${ }^{23}$ www.lbhapik.or.id
} 


\section{Conclusion}

Justice in polygamy is comprehensive justice without the violence experienced by one of his wives and children, justice like this is very difficult because it is fair to feel that a wife is not a husband. The fact says polygamy marriage is violence from all aspects wrapped in the household ranging from psychological, physical, overriding responsebilities such as not supporting both physically and mentally, quarrels between wives, quarrels between children, fighting over inheritance. For this reason, it is appropriate that the Indonesian state begins to change in favor of a woman and adheres to a monogamous law like the Turkish state.

\section{BIBLIOGRAPHY}

Ali, A.Mukti, Memahami Beberapa Aspek Ajaran Islam, Cet ke II, Bandung: Mizan,1993.

Budiman, Arif, Pembagian Kerja Secara Seksual: Sebuah Pembahasan Sosiologis Tentang Peran Wanita Di Dalam Masyarakat. Jakarta: Gramedia, 1985.

Stowasser, Barbara Freyer, Reinterpretasi Gender Wanita dalam al-Qur'an Hadis dan Tafsir, terj. (t.th)

Arifin. Busthanul, Pelembagaan Hukum Islam di Indonesia :Akar Sejarah, Hambatan Dan Prospeknya, (t.tp). Gema Insani Press, 1996.

Gokkel, H.R.W dan N.van der wal. Juridisch Latinjn, (terj) Jakarta: Intermasa, 1986.

Bakar, Imam Taqiuddin Abi, Kifayat Al-Ahyar Fi Halli Ghayat Al-Ihtishar, , Surabaya: Hidayah, (t.th).

Mubarok. Jaih, Pembahurauan Hukum Perkawinan di Indonesia, Bandung: Simbiosa Rekatama Media, 2015.

Nasution. Khoiruddin, Hukum Perdata (Keluarga) Islam Indonesia Perbandingan Hukum Perkawinan di Dunia Muslim, cet. ke-1, Yogyakarta: Academia Tazzafa, 2009.

Lufaefi, Mengkaji Pasal-Pasal Bias Gender Uu Perkawinan: Tawaran Pencegahan Kekerasan Terhadap Perempuan, Ahkam Volume 6 Nomor 2, 2018

Fajar, M. Samson, Keadilan Dalam Hukum Islam (Tinjauan Multidisipliner Dalam Kasus Poligami ) 34| Al-'Adalah Vol. Xii, No. 1 Juni 2014

Mulia, Siti Musdah, Islam Menggugat Poligami, Jakarta: PT Gramedia Pustaka Utama, 2004 .

Muthahhari, Murtadha, Al-'Adl Ilahy (trj), Bandung: Mizan, 1992.

Hasan, Riffat dan Mernissi, Fatimah. Setara di Hadapan Allah, Yogyakarta: LSPPA, 2000. 
Wahidullah, Murniati, Yushinta, Jumaiyah, Reformulation of Family Legal in Indonesia for... |125

Hikmah, Siti, Fakta Poligami Sebagai Bentuk Kekerasan Terhadap Perempuan, Sawwa Volume 7, Nomor 2, April 2012

Mertokusumo, Sudikno, Mengenal Hukum Suatu Pengantar, cet. V, Universitas Atma Jaya Yogjakarta: Yogjakarta. 2010

Rasjid, Sulaiman, Fiqh Islam, Jakarta: Attahiriyyah, (t.th)

Ahmad, Wahid Syarifuddin, Status Poligami Dalam Hukum Islam (Telaah atas Berbagai Kesalahan Memahami Nash dan Praktik Poligami), Al-Ahwal, Vol. 6, No. 1, 2013 www.lbhapik.or.id 
126 | Asy-Syari'ah Vol. 22 No.1, Juni 2020 
Asy-Syari'ah (P-ISSN: 2086-9029 E-ISSN: 2654-5675) is a periodical scientific journal that publishes various results of studies and research, literature review, and other scientific works whose scope covers the field of Islamic law/sharia, law and society in monodisciplinary, interdisciplinary, and multidisciplinary manners. The journal aims to expand and create innovative concepts, theories, paradigms, perspectives and methodologies in the above said scope. The Journal is published twice a year (june and december) by Faculty of Shariah and Law, Sunan Gunung Djati State Islamic University Bandung in collaboration with Asosiasi Sarjana Syariah Indonesia (ASSYI).

\section{EDITORIAL OFFICE:}

Fakultas Syariah dan Hukum UIN Sunan Gunung Djati Bandung J1. Raya A.H. Nasution No. 105 Cibiru Kota Bandung, 40614

Tlp/Fax: +022-7802278 Faks. 022-7802278

Website http://journal.uinsgd.ac.id/index.php/asy-syariah/index

E-mail: Jurnalasy-syariah@uinsgd.ac.id 